\title{
Influence of the arm position in myocardial perfusion imaging acquisition
}

Marisa Izakı*, José Soares Junior, Maria Clementina Pinto Giorgi, Jose Claudio Meneghetti

\section{SUMmARY}

Objective: despite the technologic advances in myocardial perfusion imaging, we keep using an uncomfortable and sometimes impracticable patient position - supine with arms raised above the head $(\mathrm{U})$. The purpose of this study was to investigate whether perfusion and functional cardiac gated SPECT scan results of acquisition $U$ are equivalent to another position modality: supine with arms down at the sides of the trunk (D).

Methods and Results: we performed $U$ acquisition and in sequence $D$ acquisition in 120 patients (pts) using a one-day MPI (rest-gated/stress), with 99mTc-sestamibi $(370 \mathrm{MBq}$ and $1110 \mathrm{MBq})$. Images were processed by the iterative reconstruction method (OSEM). Rest (R) and stress (S) studies were scored using 17 -segments model. Functional parameters (left ventricular ejection fraction, and volumes) were automatically obtained by the quantitative gated SPECT (QGS) program. According to the degree of stress defects observed in U study, the patients were categorized in two subgroups: normal (SSS $\leq 3$ or $<5 \%$ ) and abnormal (SSS $>3$ or $\geq 5 \%$ ). Shoulder/back pain occurred in $23.3 \%$ of U patients and in $5 \%$ of D. No significant differences between $U$ and D were found for SSS $(\mathrm{p}=0.82)$ and SRS $(\mathrm{p}=0.74)$ in normal group. In abnormal group, good correlation was found between $U$ and D modes for SSS $(R h o=0.95, p=0.0001)$ and SRS (Rho $=0.96 \mathrm{p}=0.0001)$, but the mean SSS $(12.53 \pm 7.54)$ and SRS $(10.60 \pm$ $7.08)$ values of $D$ were significantly lower $(p<0.05)$ than SSS $(13.43 \pm 6.81)$ and SRS $(11.33 \pm 6.97)$ of $U$ mode. Function measurements presented good correlations, except for end-diastolic volume $(\mathrm{p}=0.0001)$.

Conclusion: although D mode appears to be more comfortable and presented a good correlation with $U$ values of SSS and SRS, in abnormal pts, the extent and severity of defects can be underestimated. Considering clinical implications of an accurate perfusion measurement, the acquisition with the arms down should be avoided.

Keywords: artifacts, image interpretation, computer-assisted, radiopharmaceuticals/diagnostic use, technetium Tc $99 \mathrm{~m}$ sestamibi/diagnostic use, tomography, emission-computed, single-photon/methods.

\section{INTRODUCTION}

Myocardial perfusion imaging (MPI) with single photon emission computed tomography (SPECT) is part of routine clinical cardiology because of its value for the diagnosis and risk stratification of coronary artery disease (CAD). ${ }^{1}$ The ability of MPI for predicting future cardiac events has been strongly demonstrated., ${ }^{2,3}$ The extent and severity of stress perfusion defects and the left ventricular ejection fraction are used to stratify the likelihood of future events and to help define which patients have a short-term benefit from revascularization. ${ }^{4-6}$ 
SPECT images are affected by a variety of image degrading processes. Many technologic advances in equipment and in reconstruction algorithms have been made to increase image quality and to reduce the noise in the reconstructed SPECT images..$^{7-10}$ However, since the introduction of cardiac SPECT imaging decades ago, to avoid increasing attenuation and minimize the distance between the thorax and the camera, the patient remains routinely positioned in supine position with the arms raised above the head. ${ }^{11,12}$

In clinical practice, this is a very uncomfortable and sometimes impracticable position. About 20 to $33 \%$ of population present shoulder pain, and it is more common in women than man and increases with age. ${ }^{13}$ Many patients referred to myocardial scintigraphy have post-stroke motor sequel with consequent great difficulties in arms up positioning. Despite advances in SPECT hardware and software, in patients with difficulty to remain static, motion artifacts are a potential cause of error. Prone imaging has been reported to produce less patient motion and less inferior wall attenuation than supine imaging, ${ }^{14}$ but even in prone position, the arms are held above the head.

Just few studies ${ }^{15-17}$ with no large series, analyzed the value of the MPI with SPECT acquired with the patient's arms positioned at their sides. The findings of these papers comparing myocardial perfusion results with the arms in up and down position are contradictory. Thus, no strong evidence is available about the impact of changes in resolution caused by the presence of the arm between the detector and the heart and if this position can be used in routine clinical practice.

Furthermore, no study compared the reproducibility of gated SPECT measurement of myocardial function between these positions.

Our objective was to evaluate whether the perfusion and function results of MPI with SPECT acquired with the patients' arms in down position are comparable to the results obtained with the patients' arms in up position.

\section{Methods}

\section{Patient population}

In this prospective study, which was approved by the local ethics committee, 120 patients ( 83 men and 37 women; mean age $59 \pm 11$ years; range 36 to 82 years) who were referred for myocardial perfusion imaging were enrolled. All patients have signed informed consent.
The patients underwent either physical stress testing or pharmacologic stress (dipyridamole, adenosine or dobutamine) testing, according to their physician request. At the end of the study, we checked for the occurrence of back or arm pain and asked for the most comfortable acquisition position.

The thoracic circumference was measured excluding the arms (arms in up position) and including the arms (arms in down position). Clinical characteristics of the patient population are given in Table 1.

TABLE 1 Clinical characteristics of the patient population

\begin{tabular}{|c|c|}
\hline & $\begin{array}{l}\text { Population } \\
(n=120)\end{array}$ \\
\hline Male sex & $83(69 \%)$ \\
\hline $\begin{array}{l}\text { Age }(y)[\text { mean } \pm S D \\
(\text { minimum-maximum })]\end{array}$ & $59.36 \pm 11.36(36-82)$ \\
\hline $\begin{array}{l}\text { Weight }(\mathrm{kg})[\text { mean } \pm \mathrm{SD} \\
(\text { minimum-maximum })]\end{array}$ & $72.8 \pm 14(32-120)$ \\
\hline $\begin{array}{l}\text { Height }(\mathrm{m})[\text { mean } \pm S D \text { (minimum- } \\
\text { maximum })]\end{array}$ & $1.65 \pm 0.09(1.44-1.98)$ \\
\hline Body mass index $\left(\mathrm{Kg} / \mathrm{m}^{2}\right)($ mean $\pm \mathrm{SD})$ & $26.54 \pm 3.75$ \\
\hline $\begin{array}{l}\text { Thoracic circumference excluding arms } \\
(\mathrm{cm})(\text { mean } \pm \mathrm{SD})\end{array}$ & $100.3 \pm 9.2$ \\
\hline $\begin{array}{l}\text { Thoracic circumference including arms } \\
(\mathrm{cm})(\text { mean } \pm S D)\end{array}$ & $120 \pm 9.8$ \\
\hline Angina (\%) & 34 \\
\hline Hypertension (\%) & 39 \\
\hline Diabetes mellitus (\%) & 10 \\
\hline History of coronary artery disease (\%) & 49 \\
\hline Myocardial infarction (\%) & 30 \\
\hline Percutaneous coronary intervention (\%) & 19 \\
\hline Coronary artery bypass grafting (\%) & 33 \\
\hline
\end{tabular}

\section{Data acquisition}

All patients underwent same-day rest-stress technetium$-99 \mathrm{~m}$ labeled sestamibi (99mTc-sestamibi). SPECT myocardial perfusion scintigraphy and electrocardiographic-gated acquisition was performed only in stress imaging. In both parts (rest and stress), the first acquisition was done with the patients in supine position with the arms raised above the head $(\mathrm{U})$ and immediately following the standard $U$ position, the patient was placed in supine position with arms down at the sides of the trunk (D), as illustrated in Figure 1. 


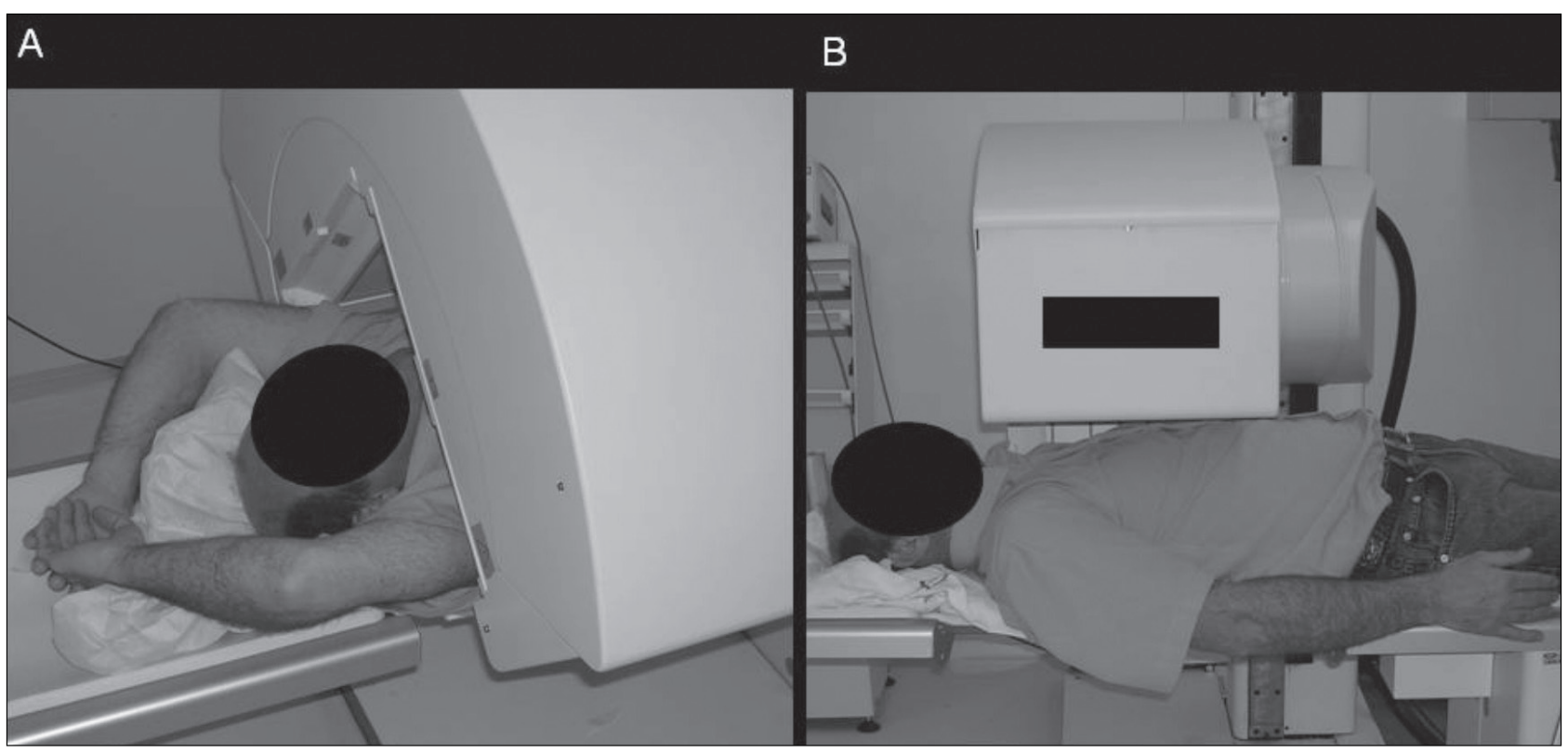

FIGURE 1 Part A: shows an example of a patient in supine position with the arms raised above the head $(U)$, part B: shows the patient in supine position with arms down at the sides of the trunk (D).

A dose of $370 \mathrm{MBq}$ of $99 \mathrm{mTc}$-sestamibi (Cardiolite, Bristol-Myers Squibb Medical Imaging) was injected at rest and the acquisitions were performed 60 to 90 minutes later. Sixty-four patients performed a symptom-limited exercise treadmill test with standard Ellestad protocol. At near-maximal exercise $1110 \mathrm{MBq}$ of 99mTc-sestamibi was injected. Fifty-five patients received the $1110 \mathrm{MBq}$ of $99 \mathrm{mTc}$-sestamibi during pharmacologic stress test with adenosine $(140 \mu \mathrm{g} / \mathrm{kg} / \mathrm{min}$ for 6 minutes) or four minutes after dipyridamole infusion $(0.56 \mathrm{mg} / \mathrm{kg} / \mathrm{min}$ for 4 minutes). One patient performed dobutamine stress test and $1110 \mathrm{MBq}$ of $99 \mathrm{mTc}$-sestamibi was injected during the infusion of $40 \mu \mathrm{g} / \mathrm{kg} / \mathrm{min}$ of dobutamine. Stress perfusion scintigraphy acquisitions started 30 to $60 \mathrm{minu}-$ tes later.

Paired studies were performed on commercially available SPECT systems: 37 Sophy camera-DST (GE Medical Systems), 38 on Cardio-MD (Adac-Phillips) and 45 on Forte (Adac-Phillips). The gamma cameras were equipped with low-energy, high-resolution, parallel-hole collimators. The data were acquired in $64 \times 64$ matrix for 64 projections over a 180 -degree, non-circular orbit extending from $45^{\circ}$ right anterior oblique to left posterior oblique. Each rest projection was acquired for 25 seconds and each stress gated-projection for 30 seconds, at 8 frames per R-R interval. The acquisition was repeated when patient motion occurred or if prominent activity adjacent to the heart was present. Attenuation correction, scatter correction and collimator response compensation were not applied.

All data were processed on the Pegasys 4.2 system (ADAC-Philips), Pegasys 5.0 system (ADAC-Philips) or Vision PowerStation system (GE Medical Systems) and transaxial tomograms were reconstructed by the use of iterative reconstruction method (OSEM) with an initial starting point obtained by filtered back-projection method. Vertical long-axis, horizontal long-axis, and short-axis tomograms were derived from transaxial images.

\section{Perfusion and function analysis}

The interpretation of $U$ and $D$ images were based on short-axis and vertical long-axis tomograms divided into 17 segments, totalizing 2040 segments. Rest and stress segments of $U$ and $D$ were interpreted blindly by three experienced nuclear medicine physicians separately, using a 5 -point scoring system $(0$, normal; 1 , mildly abnormal; 2 , moderate abnormal; 3 , severe abnormal; and 4 , absence of segmental uptake). In both studies (U and D), summed scores for stress (SSS) and for rest (SRS) were calculated by summing of respective segmental scores. The SSS and SRS values were converted to a percentage (\%) of the total myocardium involved dividing the summed scores by 68 , the maximum potential score $(4 \times 17)$, and multiplying by 100 .

The degree of stress defects was defined as: normal or minimally abnormal if involving less than $5 \%$ of the 
myocardium, mildly abnormal if involving 5 to $9 \%$, moderately abnormal if involving 10 to $14 \%$ and severely abnormal if are greater than $15 \%$ of the myocardium area.

According to the degree of stress defects observed in U study, the patients were categorized in two subgroups: normal (SSS $\leq 3$ or $<5 \%$ ) and abnormal (SSS $>3$ or $\geq 5 \%$ )

Left ventricular ejection fraction (LVEF), end-diastolic (EDV) and end-systolic volumes (ESV) were determined automatically by the use of QGS software (Cedars Sinai Medical Center, Los Angeles, Calif). We considered the lower normal limit of the EF $51 \%$ in women and $43 \%$ in men, the upper normal limit of EDV $102 \mathrm{~mL}$ for women and $149 \mathrm{~mL}$ for men and the upper normal limit of ESV $46 \mathrm{~mL}$ for women and $75 \mathrm{~mL}$ for men.

\section{Statistical analysis}

Data were expressed as mean, standard deviation (SD)

Overall agreement for perfusion findings between $U$ and D modes was calculated on a per-segment basis, SSS and SRS values. Correlation of SSS and SRS values between $\mathrm{U}$ and D measurements were evaluated with the Spearman (Rho) value. Comparisons of variables were made using Wilcoxon signed-ranks test.

Comparisons between volumes and LVEFs of measurements made by repeated $U$ and D SPECT were evaluated with the paired $t$ test.

A P value of $<0.05$ was considered to indicate statistical significance.

\section{Results}

\section{General findings}

The thoracic circumference with the arms in down position was about $20 \%$ greater than the circumference with the arms in up position (mean $120 \pm 9.8 \mathrm{~cm}$ and $100 \pm$ $9.2 \mathrm{~cm}$, respectively).

Fifty-three patients (44\%) choose arms up position as more comfortable and sixty-seven ones (56\%) preferred arms down position. Left arm, shoulder or back pain symptoms were reported for 28 patients $(23 \%)$ in U mode against six patients (5\%) in D mode.

\section{Perfusion findings}

The comparison of the 2040 segments obtained from the 120 studies demonstrated significant differences in the scores of $\mathrm{U}$ and $\mathrm{D}$, at rest scans $(\mathrm{P}=0.001$; Wilcoxon signed-ranks test) and at stress scans $(\mathrm{P}=0,0001$; Wilcoxon signed-ranks test).

According $\mathrm{U}$ mode findings, 80 patients were classified as normal and 40 patients as abnormal (SSS ranging from 4 to 30 ).

No significant differences were found between $U$ and $D$ in normal group, at stress $(\mathrm{P}=0.82)$ and rest $(\mathrm{P}=0.74)$ scans.

In abnormal group, good correlation was observed between $\mathrm{U}$ and $\mathrm{D}$ values of SSS ( $\mathrm{Rho}=0.95 ; \mathrm{P}=0.0001)$ and SRS (Rho $=0.96 ; \mathrm{P}=0.0001)$ (Figure 2).

However, SSS and SRS values of the matched scans differed significantly $(\mathrm{p}=0.0083$ and $\mathrm{p}=0.0249$; respec-
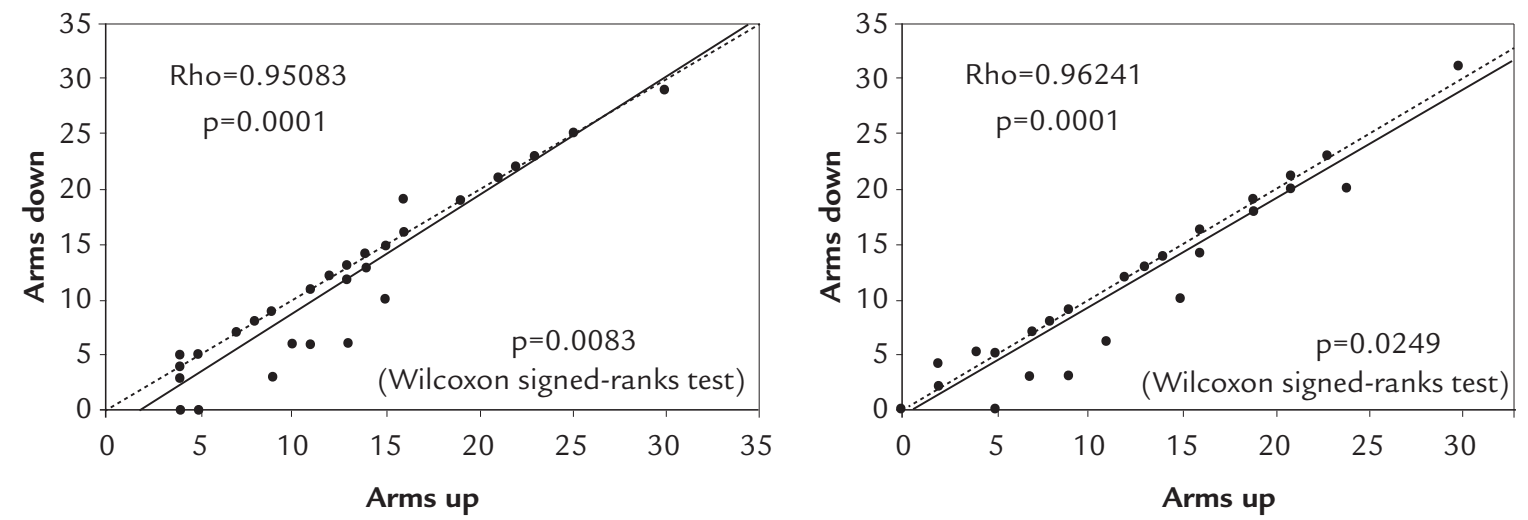

FIGURE 2 Correlation between SSSs and SRSs from U position and D position in the abnormal patients group. 
tively). The mean value of SSS (12.53 \pm 7.54$)$ and SRS (10.6 \pm 7.08$)$ found in D acquisition were significantly lower than the mean values of SSS $(13.43 \pm 6.81)$ and SRS (11.33 \pm 6.97$)$ observed in $U$ acquisition.

Among abnormal scans patients, 17 patients presented mildly abnormal, 8 ones moderately abnormal and 15 ones severely abnormal scans. Compared to U imaging, $\mathrm{D}$ position is associated with lower amount of perfusion abnormalities in 26 patients (22\%) and in 14 patients $(12 \%)$ an underestimation in the degree of the disease occurred.

\section{FUNCTION FINDINGS}

Two patients had non-regular heart rhythm, so the studies could not be performed with ECG triggering.

Among 118 patients evaluated, no statistical differences were found between $U$ and D SPECT images in terms of LVEF and ESV (P > .05), but EDV differed significantly $(\mathrm{P}=0.0001)$. The results of LVEF, ESV and EDV obtained in $\mathrm{U}$ and $\mathrm{D}$ mode are shown in Table 2.

In standard $U$ position, 95 patients presented normal LVEF values and 23 patients presented abnormal values according to gender. Comparing $\mathrm{U}$ and $\mathrm{D}$ modes, just seven patients changed the values of LVEF from normal to abnormal or from abnormal to normal in the repeated acquisitions.

\section{Discussion}

Just few data are available about how much the arm position really affects myocardial perfusion images, ${ }^{15-17}$ and this is the first study to analyze the influence of arm position in the left ventricular function evaluation.

As expected, the arms down position appears to be more comfortable and cause less pain.

However, in our study the comparison of perfusion results was not so favorable.
In normal patients, no differences were found, but in abnormal patients, the SSS and SRS values were not equivalents. In abnormal patients, using arms down position, the amount of perfusion abnormalities can be underestimated. The underestimation of the myocardial lesion may interfere with clinical evaluation and management, since the severity and extent of cardiac SPECT perfusion abnormalities are clinically used in prognostic assessment and therapeutic management of patients with suspected or known coronary artery disease.

Toma et al. ${ }^{16}$ assessed the influence of arm positioning in MPI using 99mTc-sestamibi in 41 patients. These authors concluded that arm positioning does not influence the interpretation of MPI with regard to image quality or defect location and extent. Our present study demonstrates results which are not consistent to this previous study. However, in this previous study, more than half of the population was interpreted as normal in both positions. In our study, also no significant differences were found in normal patients. The perfusion differences were observed exactly in the abnormal patients group. More comparable with our study findings, although using 201-tallium as tracer, prior investigation ${ }^{17}$ has reported that mean segmental relative uptake values for arms up position studies were higher than for arms down position studies across the majority of the myocardium, especially in anterolateral region. Another research, ${ }^{15}$ reported in abstract form, concluded that only the inferior wall of the heart was unaffected by left arm position. All of these studies evaluated small populations and none of them analyzed normal and abnormal groups distinctly.

SPECT images are affected by a variety of image degrading processes such as tissue attenuation. Superimposition of left arm over the lateral part of the heart may result in areas of relatively decreased activity in MPI. It might be one of the factors to explain the differences

TABLE 2 Results of LVEF (left ventricular ejection fraction), EDV (end-diastolic volume) and ESV (end- systolic volume) values according to arm position

\begin{tabular}{|c|c|c|c|c|c|c|c|}
\hline & Arm position & $\mathbf{n}$ & Mean & SD & Minimum & Maximum & $\mathbf{P}^{*}$ \\
\hline \multirow[t]{2}{*}{ FEVE } & Arms up & 118 & 54.53 & 14.03 & 18 & 81 & \multirow[t]{2}{*}{0.0527} \\
\hline & Arms down & 118 & 53.93 & 14.45 & 17 & 83 & \\
\hline \multirow[t]{2}{*}{ EDV } & Arms up & 118 & 109.22 & 50.57 & 46 & 369 & \multirow[t]{2}{*}{0.0001} \\
\hline & Arms down & 118 & 105.88 & 50.15 & 45 & 363 & \\
\hline \multirow[t]{2}{*}{ ESV } & Arms up & 118 & 55.27 & 45.18 & 9 & 303 & \multirow[t]{2}{*}{0.0826} \\
\hline & Arms down & 118 & 54.37 & 44.59 & 8 & 299 & \\
\hline
\end{tabular}

* paired t test 
found, but certainly it's not the unique. If left arm attenuation were a main factor, it was expected that differences were noticed as much in normal as in abnormal groups. Furthermore, arm attenuation probably would cause an overestimation of the defects, not an underestimation as observed in our results.

The resolution of a gamma camera is depth-dependent, so increase in source-to-detector distance may result in variation of spatial resolution and loss of fine details in SPECT images. In our population, the thoracic circumference with the arms in down position was about $20 \%$ greater than the circumference with the arms in up position. So increased source-to-detector distance in arms down acquisition, may explain the differences observed between arms down and up scan results, especially in abnormal patients where fine details are important in the interpretation of the images.

In our study, we performed a non-circular orbit, which has the advantage of minimizing the distance between the patient and the camera throughout the scan. However, due to increased variation of source-to-detector distance, resulting in variation of spatial resolution, some artifacts may be observed.

The acquisition projections that are tangential to a particular segment of the left ventricular wall are of primary importance in defining the shape and count distribution in that segment of the reconstructed slice. Abufadel et al. ${ }^{18} \mathrm{de}-$ monstrated that there was a significant loss of counts at the apex relative to other regions of the left ventricle. It results in more blurring in the projection of the apex and became larger as the orbit became more and more elliptic.

Physiological process may be evolved too. Hemodynamic variations occur during postural changes. Compared to supine imaging, the prone position is associated with a change in the location of the heart in the chest. Pump et al. ${ }^{19}$ analyzing the effects of horizontal posture in cardiovascular variables demonstrated that prone position decreases stroke volume and increases sympathetic nervous activity, heart rate and total peripheral vascular resistance. Mckeough et al. ${ }^{20}$ observed that arm positioning above the head places the chest wall in an inflated position. Therefore, arm position alters lung volumes, so probably the heart position in the chest also is altered.

With regard to measurement of myocardial function, great degree of reproducibility between ejection fractions and end-systolic volume were observed in two positions.

The functional evaluation seems to be less affected by the arm position.

In our study, sequential acquisitions (arms up and arms down) were performed. Therefore variation in the time course of actual change in volumes and ejection fraction was minimized. However, left ventricular end-diastolic volume differed significantly, maybe related to physiological modifications.

\section{LIMITATIONS}

The supine position with arms above the head is routinely used for SPECT imaging; therefore it was considered the standard position. The comparison was not based on coronary angiography or other imaging modalities results. However, the aim of the study was not to define the accuracy of the procedures. The present study examines the repeatability of myocardial perfusion imagines in different arm positions.

Attenuation correction, scatter correction and collimator response compensation were not applied. These recent innovations in hardware and software have provided the capabilities for improved spatial resolution and contrast, and it's not established how much the use of these innovations could improve arms down scan diagnostic performance. ${ }^{21,22}$

\section{Conclusion}

Arms down position seem to be more comfortable and cause less pain than arms up position.

MPI SPECT acquired with the patients' arms in down position presented perfusion findings comparable with the results of patients' arms in up position, just in normal patients.

In abnormal scans perfusion abnormalities may be underestimated.

The functional evaluation seems to be less affected by the arm position. Great degree of reproducibility between ejection fractions and end-systolic volume were observed in two positions. Significant differences were found in end-diastolic volume measurement.

Therefore, considering the important therapeutic and prognostic implications of an accurate perfusion measurement, the cardiac SPECT acquisition with the arms in down position should be avoided.

\section{Resumo}

Influência da posição dos braços na aquisição da cintilografia do miocárdio.

Objetivo: no estudo de perfusão miocárdica, apesar dos avanços tecnológicos, continuamos utilizando o desconfortável e às vezes impraticável posicionamento em decú- 
bito dorsal com braços acima da cabeça (U). O objetivo do estudo foi investigar se os resultados da perfusão e da função cardíacas obtidos com a aquisição U são equivalentes ao de outra modalidade de posição: com braços para baixo nas laterais do tronco (D).

Métodos e resultados: adquirida a aquisição U, na sequência foi realizada a aquisição D em 120 pacientes (pts) em um único dia (repouso e estresse sincronizado ao ECG), com 99mTc-sestamibi (370 MBq e $1110 \mathrm{MBq}$ ). As imagens foram processadas usando reconstrução iterativa (OSEM). Cada estudo foi quantificado usando o modelo de 17-segmentos ao repouso (R) e ao estresse (S). Os parâmetros funcionais (fração de ejeção do ventrículo esquerdo e volumes) foram obtidas automaticamente pelo programa gated SPECT quantitativa (QGS). De acordo com a dimensão da alteração perfusional no estresse na aquisição U, os pacientes foram classificados em dois subgrupos: 80 pts normais (SSS $\leq 3$ ou $<5 \%$ ) e 40 pts anormais (SSS $>3$ ou $\geq 5 \%$ ). Dor no ombro e/ou nas costas ocorreu em $23,3 \%$ dos pacientes de $\mathrm{U}$ e em $5 \%$ de $\mathrm{D}$. Não houve diferenças significativas entre U e D quanto ao SSS $(\mathrm{p}=0,82)$ e SRS $(\mathrm{p}=0,74)$ no grupo normal. No grupo anormal, boa correlação foi encontrada entre U e D para SSS $($ Rho $=0,95, \mathrm{p}=0,0001)$ e SRS (Rho $=0,96 \mathrm{p}=0,0001)$, entretanto a média dos valores de SSS $(12,53 \pm 7,54)$ e SRS $(10,60 \pm 7,08)$ de D foram significativamente menores $(\mathrm{p}<0,05)$ que o SSS $(13,43 \pm 6,81)$ e SRS $(11,33 \pm 6,97)$ de U. As medidas de função apresentaram boas correlações, exceto para o volume diastólico final $(\mathrm{p}=0,0001)$.

Conclusão: embora o modo D pareça ser mais confortável e apresente boa correlação com valores de SSS e SRS do modo $U$, em pacientes anormais, a extensão e a gravidade dos defeitos podem ser subestimadas. Considerando as implicações clínicas da precisa avaliação da extensão de alterações na perfusão miocárdica, a aquisição com os braços para baixo deve ser evitada.

Unitermos: artefatos, interpretação de imagem assistida por computador, compostos radiofarmacêuticos/uso diagnóstico, tecnécio Tc $99 \mathrm{~m}$ sestamibi/uso diagnóstico, tomografia computadorizada de emissão de fóton único/métodos.

\section{References}

1. Underwood SR, Anagnostopoulos C, Cerqueira M, Ell PJ, et al. British Cardiac Society; British Nuclear Cardiology Society; British Nuclear Medicine Society; Royal College of Physicians of London; Royal College of Radiologists. Myocardial perfusion scintigraphy: the evidence. Eur J Nucl Med Mol Imaging. 2004 Feb;31(2):261-91. Review.
2. Clark AN, Beller GA. The present role of nuclear cardiology in clinical practice.Q J Nucl Med Mol Imaging. 2005 Mar;49(1):43-58. Review.

3. Russell RR 3rd, Zaret BL.Nuclear cardiology: present and future. Curr Probl Cardiol. 2006 Sep;31(9):557-629. Review.

4. Hachamovitch R, Berman DS, Shaw LJ, Kiat H, Cohen I, Cabico JA, Friedman $\mathrm{J}$, et al. Incremental prognostic value of myocardial perfusion single photon emission computed tomography for the prediction of cardiac death: differential stratification for risk of cardiac death and myocardial infarction. Circulation. 1998;97(6):535-43. Erratum in: Circulation. 1998;98(2):190.

5. Hachamovitch R, Hayes SW, Friedman JD, Cohen I, Berman DS. Comparison of the short-term survival benefit associated with revascularization compared with medical therapy in patients with no prior coronary artery disease undergoing stress myocardial perfusion single photon emission computed tomography. Circulation.2003;107(23):2900-7.

6. Hachamovitch R, Berman DS. The use of nuclear cardiology in clinical decision making. Semin Nucl Med. 2005 Jan;35(1):62-72. Review.

7. Groch MW, Erwin WD. SPECT in the year 2000: basic principles. J Nucl Med Technol. 2000;28(4):233-44.

8. Beekman FJ, Kamphuis C, King MA, Van Rijk PP, Viergever MA. Improvement of image resolution and quantitative accuracy in clinical Single Photon Emission Computed Tomography. Comput Med Imaging Graph. 2001 MarApr;25(2):135-46. Review.

9. Germano G. Technical aspects of myocardial SPECT imaging. J Nucl Med. 2001; 42(10):1499-507.

10. Paul AK, Nabi HA. Gated myocardial perfusion SPECT: basic principles, technical aspects, and clinical applications. J Nucl Med Technol. 2004 Dec;32(4):179-87. Review.

11. Hesse B, Tägil K, Cuocolo A, Anagnostopoulos C, Bardiés M, Bax J, et al. EANM/ESC Group. EANM/ESC procedural guidelines for myocardial perfusion imaging in nuclear cardiology. Eur J Nucl Med Mol Imaging. 2005 Jul;32(7):855-97

12. Hansen CL, Goldstein RA, Akinboboye OO, Berman DS, et al. American Society of Nuclear Cardiology. Myocardial perfusion and function: single photon emission computed tomography. J Nucl Cardiol. 2007 NovDec;14(6):e39-60. Review.

13. McBeth J, Jones K. Epidemiology of chronic musculoskeletal pain. Best Pract Res Clin Rheumatol. 2007;21(3):403-25. Review.

14. Peterson PN, Parker JA, Tepper MR, Hauser TH, English J, Danias PG. Prone SPECT myocardial perfusion imaging is associated with less cardiac drift during the acquisition duration than imaging in the supine position. Nucl Med Commun. 2005 Feb;26(2):115-7.

15. Cantinho G, Pena H, Veiga A, Marques V, Godinho F. Left arm position Effect of attenuation correction on myocardial tracer distribution. J. Nucl Cardiol. 1999;6(suppl):S28 (Presented at $4^{\text {th }}$ Internatinal Conference of Nuclear Cardiology; 1999 April 18-21; Athens, Greece. Abstracts

16. Toma DM, White MP, Mann A, Phillips JM, Pelchat DA, et al. Influence of arm positioning on rest/stress technetium-99m labeled sestamibi tomographic myocardial perfusion imaging. J Nucl Cardiol. 1999; 6(2):1638.

17. Prvulovich EM, Jarritt PH, Lonn AHR, Vorontsova E, Bomanji JB, Ell PJ Influence of arm positioning on tomographic thallium-201 myocardial perfusion imaging and the effect of attenuation correction. Eur J Nucl Med. 2000; 27(9):1349-1355.

18. Abufadel A, Eisner RL, Schafer RW. Differences due to collimator blurring in cardiac images with use of circular and elliptic camera orbits. J Nucl Cardiol. 2001 Jul-Aug;8(4):458-65

19. Pump B, Talleruphuus U, Christensen NJ, Warberg J, Norsk P.Effects of supine, prone, and lateral positions on cardiovascular and renal variables in humans.Am J Physiol Regul Integr Comp Physiol. 2002 Jul;283(1):R174-80.

20. McKeough ZJ, Alison JA, Bye PT. Arm positioning alters lung volumes in subjects with COPD and healthy subjects. Aust J Physiother. 2003;49(2):133-7.

21. Links JM, Becker LC, Rigo P, Taillefer R, Hanelin L, Anstett F, et al. Combined corrections for attenuation, depth-dependent blur, and motion in cardiac SPECT: a multicenter trial. J Nucl Cardiol. 2000 Sep-Oct;7(5):414-25.

22. El Fakhri G, Buvat I, Benali H, Todd-Pokropek A, Di Paola R. Relative impact of scatter, collimator response, attenuation, and finite spatial resolution corrections in cardiac SPECT. J Nucl Med. 2000 Aug;41(8):1400-8. 